\title{
Studi Etnomatematika terhadap Para Pengrajin Payung Geulis Tasikmalaya Jawa Barat
}

\author{
Siska Ryane Muslim¹, Mega Nur Prabawati2* \\ Program Studi Pendidikan Matematika, Universitas Siliwagi \\ Jalan Siliwangi No. 24, Tasikmalaya, Jawa Barat, Indonesia \\ ${ }^{1}$ siskaryanemuslim@unsil.ac.id, ${ }^{2 *}$ meganurprabawati@unsil.ac.id
}

Artikel diterima: 23-11-2019, direvisi: 28-01-2020, diterbitkan: 31-01-2020

\begin{abstract}
Abstrak
Penelitian dilatarbelakangi pertentangan opini mengenai hubungan matematika dengan budaya, yang mengarah pada ethnomathematics. Tujuan penelitian untuk mengetahui serta mendeskripsikan etnomatematika pada pembuatan Payung Geulis Tasikmalaya. Metode penelitian yaitu kualitatif dengan metode etnografi. Subjek penelitian dipilih melalui metode purposive sampling, yaitu tiga orang pengrajin Payung Geulis yang berada di Panyingkiran, Indihiang, Kota Tasikmalaya serta telah menjadi pengrajin selama lebih dari 10 tahun. Teknik pengumpulan data yaitu dengan observasi, wawancara dan dokumentasi. Instrumen penelitian yaitu peneliti sendiri dengan didukung beberapa instrumen lainnya yaitu pedoman observasi, pedoman wawancara, alat rekam dan kamera. Teknik analisis data yang digunakan dalam penelitian ini yaitu reduksi data, penyajian data dan menarik kesimpulan atau verifikasi. Berdasarkan hasil analisis data, disimpulkan bahwa terdapat kaitan antara Payung Geulis dengan matematika yang ditunjukkan dengan adanya unsur-unsur matematika berdasarkan konsep geometri. Konsep geometri tersebut diantaranya berupa geometri bangun datar, geometri bangun ruang, simetri, geometri transformasi (refleksi, translasi, dan rotasi) serta kekongruenan.

Kata Kunci: Payung Geulis, Geometri, Etnomatematika.
\end{abstract}

\section{Ethnomathematics Study of Payung Geulis Craftmans Tasikmalaya}

\begin{abstract}
Research is motivated by conflicting opinions about the relationship between mathematics and culture, which leads to ethnomathematics. This research aims to determine and describe ethnomathematics in the manufacture of Tasikmalaya Geulis Umbrellas. The research method is qualitative with ethnographic methods. The subjects in this study were selected using a purposive sampling method where the subject was a Payulis Geulis craftsman in Panyingkiran, Indihiang, Tasikmalaya City and had been a craftsman for more than 10 years. Data collection techniques used are observation, interview, and documentation. The research instrument was the researcher himself, supported by several other instruments, namely observation guidelines, interview guidelines, recording equipment, and cameras. Data analysis techniques used in this study are data reduction, data presentation and drawing conclusions or verification. Based on the results of data analysis, it was concluded that there is a relationship between Umbrella Geulis with mathematics which is indicated by the existence of mathematical elements based on the concept of geometry. The geometrical concepts include the geometry of the flat structure, geometry of geometry, symmetry, the geometry of transformation (reflection, translation, and rotation) and concordance.

Keywords: Payung Geulis, Geometry, Ethnomathematics.
\end{abstract}

Mosharafa: Jumal Pendidikan Matematika

Volume 9, Nomor 1, Januari 2020

Copyright $\odot 2020$ Mosharafa: Jurnal Pendidikan Matematika 


\section{Pendahuluan}

Pada hakikatnya, matematika merupakan induk dari ilmu pengetahuan lain dan sekaligus berperan untuk membantu perkembangan ilmu tersebut (Suherman, 2012). Dalam kehidupan sehari-hari, banyak konsep matematika yang dapat digunakan untuk menyelesaikan permasalahan yang muncul (Afriansyah, 2016). Disadari atau tidak, banyak kehidupan bermasyarakat yang menjunjung tinggi nilai-nilai budayanya telah menerapkan konsep matematika dalam setiap aktivitas budayanya.

Namun, terdapat banyak opini masyarakat yang menyatakan bahwa matematika tidak ada hubungan sama sekali dengan budaya. Seperti yang diungkapkan Sumardianta (2013) dalam salah satu artikel di surat kabar Tempo yang berjudul Mempersoalkan Kurikulum 2013, "...kurikulum, yang terbelenggu pabrikan buku dan ujian nasional, didominasi ranah kognitif sebagai simbol prestasi tertinggi. ...mendewakan matematika-IPA, dan mengabaikan humaniora-sastra". Menurut penulis, munculnya pernyataan tersebut pada surat kabar merupakan salah satu bukti bahwa selama ini matematika dipandang sebagai sesuatu yang tidak berpengaruh sama sekali terhadap budaya (humaniora-sastra) atau sebaliknya.

Turmudi (2009) menyatakan bahwa paradigma yang muncul pada masyarakat tentang matematika adalah paradigma absolut, yaitu anggapan bahwa matematika merupakan ilmu pengetahuan yang sempurna dan kebenaran yang objektif, jauh dari kehidupan manusia. Paradigma ini telah mendominasi selama lebih dari 2000 tahun. Dalam penelitian lebih lanjut, banyak ide-ide matematis yang telah digunakan masyarakat untuk menyelesaikan permasalahan yang berkaitan dengan konteks budayanya (Afriansyah, 2013). Hal ini sejalan dengan pernyataan Sumardyono (2008) bahwa "Obyek-obyek matematika bersifat sosialkultural-historis, artinya bahwa matematika dan pembelajarannya merupakan milik bersama seluruh umat. Betapa pun primitifnya suatu masyarakat, matematika adalah bagian dari kebudayaannya (meski dalam bentuk yang sederhana)".

Alasan-alasan yang sudah dijelaskan sebelumnya secara langsung mengarah ke ranah kajian ethnomathematics (etnomatematika). Alangui (2010) mengungkap bahwa etnomatematika sama dengan mentransformasi matematika, mendorong terbentuknya suatu ilmu pengetahuan yang tidak mengeksploitasi dan merendahkan, tetapi mengangkat kehidupan manusia. Sesuai dengan yang dikemukakan oleh Turnbull (Alangui, 2010). Hal yang menjadi fokus pada penelitian etnomatematika adalah untuk menginvestigasi pengaruh timbal balik antara matematika, budaya, dan sosial (Alangui, 2010).

Ethnomathematics dapat digambarkan sebagai jembatan yang menghubungkan matematika dengan gagasan serta praktik budaya lain (Barton, 1996). Bapak pendiri ethnomathematics sendiri yaitu, D'Ambrosio \& Ascher (1994), menjelaskan bahwa ethnomathematics sebagai studi tentang berbagai bentuk matematika yang muncul dari berbagai model pemikiran (Afriansyah, 2015). Beliau sangat tertarik dengan sifat pengetahuan matematika di antara budaya yang berbeda, dan hubungannya dengan sejarah matematika, filsafat dan kognisi.

Banyak penelitian tentang etnomatematika yang sudah dilakukan, diantaranya oleh 
Paraide (2008) yaitu penomoran pada budaya Tolai di Papua New Guinea. Keanekaragaman budaya sudah menjadi bahan kajian, diantaranya oleh Puspadewi dan Putra (2014) yaitu taselasi pada kerajinan anyaman Bali, Arisetyawan, Suryadi, Herman dan Rahmat (2016) yaitu matematika pada kebiasaan masyarakat Baduy Banten, dan juga Bagas Godang sebagai unsur budaya Mandailing di Sumatera Utara (Siregar, Mujib, \& Dewita, 2019).

Kembali pada gagasan utama penelitian ini, yaitu eksplorasi etnomatematika pada kelompok budaya, penulis tertarik untuk mengungkap pemikiran matematik dari para pengrajin payung geulis Tasikmalaya Jawa Barat. Payung Geulis merupakan salah satu kerajinan tradisional di Tasikmalaya Jawa Barat yang sangat indah dan sangat disenangi oleh masyarakat karena nilai estetika dan motif dari payung geulis tersebut. Kerajinan payung geulis Mandiri Tasikmalaya Jawa Barat ini merupakan salah satu upaya masyarakat di daerah Panyingkiran Kecamatan Indihiang Kota Tasikmalaya untuk melestarikan dan memunculkan kembali budaya peninggalan nenek moyang terdahulu serta meningkatkan produksi khas Tasikmalaya ini. Setelah dilakukan penelitian pendahuluan, diperoleh hasil bahwa memungkinkan untuk dilakukannya pengamatan, pencatatan, pendokumentasian, serta pengungkapan pemikiran matematik/konsep-konsep matematik pada aktivitas membuat kerajinan payung geulis di daerah Panyingkiran Kecamatan Indihiang Kota Tasikmalaya.

Aktivitas matematika yang paling jelas terlihat dan dapat dilakukan pengamatan (Afriansyah, 2014) yaitu dalam pembuatan payung geulis tasikmalaya antara lain aktivitas mengukur dan membuat pola. Aktivitas mengukur terlihat mulai dari kegiatan awal membuat kerajinan payung geulis tersebut, yaitu pembuatan rangka payung, serta pembuatan jari-jari payung geulis. Aktivitas mengukur yang dilakukan oleh pengrajin payung geulis tersebut terlihat dalam proses menentukan jarak antara jari-jari dalam tersebut antara yang satu dengan yang lainnya harus sama sehingga butuh perkiraan dan perhitungan, begitu pun sama dengan jari-jari luar yang mana antara satu jari-jari dengan jari-jari lainnya jaraknya harus sama. Pemasangan kertas/kain pada payung geulis tersebut berbentuk bulat yang besar-kecilnya tergantung ukuran payung yang dibuat. Sedangkan aktivitas membuat pola jelas terlihat pada proses pembuatan desain motif payung geulis. Berbagai aktivitas paying geulis ini mengacu pada pokok bahasan geometri.

Beberapa penelitian terdahulu telah membahas pokok bahasan geometri dari berbagai aspek, yaitu: kemampuan penalaran (Siregar, 2016), tahapan berpikir Van Hiele (Sholihah \& Afriansyah, 2017), soal-soal nonrutin (Sundawan, Irmawan, \& Sulaiman, 2019), dan Masalah TIMSS (Mulyo, Sari, \& Syarifuddin, 2019).

Mengacu kepada penjelasan Barton (1996) mengenai etnomatematika bahwa dalam setiap aktivitas matematika terdapat konsepkonsep matematika yang mungkin untuk diungkap. Pengungkapan pemikiran matematik ini selain untuk menggambarkan perkembangan intelektual masyarakat Indonesia, khususnya masyarakat kota Tasikmalaya itu sendiri, juga bertujuan agar dapat memperlihatkan hubungan timbal balik antara matematika dengan budaya, terutama konsep-konsep matematis yang berhubungan 
langsung dengan budaya masyarakat kota Tasikmalaya, sehingga dapat mengubah paradigma masyarakat tentang hubungan matematika dengan budaya itu sendiri, yang kemudian dapat dimanfaatkan dalam upaya peningkatan mutu pembelajaran matematika khususnya pada pendidikan di kota Tasikmalaya dan umumnya pada pendidikan di Indonesia.

\section{Metode}

Pada penelitian ini, peneliti memilih untuk menggunakan pendekatan kualitatif. Pemilihan metode ini bertujuan untuk mengeksplorasi pemikiran matematik dari para pengrajin payung geulis Tasikmalaya dan mengidentifikasi konsep matematika yang digunakan oleh para pengrajin payung geulis Tasikmalaya.

Untuk pendekatan dalam penelitian ini, digunakan studi kualitatif deskriptif. Tujuan penggunaan studi kualitatif deskriptif adalah untuk mengungkapkan atau memperoleh informasi dari data penelitian secara menyeluruh, luas dan mendalam (Sugiyono, 2015).

Subjek yang diteliti relatif terbatas terdiri dari tiga orang pengrajin payung geulis, namun variabel-variabel dan fokus yang diteliti sangat luas dimensinya (Danim dalam Atmanto, 2008). Dalam penelitian ini, kasus yang akan diteliti adalah sebuah gagasan/pengetahuan yang menjadi pemikiran matematik dari para pengrajin payung geulis Tasikmalaya Jawa Barat (Penelitian terhadap Pengrajin Payung Geulis Tasikmalaya Jawa Barat).

Data dari penelitian ini dianalisis untuk memperoleh deskripsi etnomatematika pada Payung Geulis. Dalam analisis subjek masingmasing diberi kode inisial untuk lebih mempermudah proses analisis. Penggodaan
Tabel 1.

Daftar Subjek Penelitian

\begin{tabular}{|ccc|}
\hline No. & Nama Subjek & Kode Subjek \\
\hline 1 & Bapak Yayat Sudrajat & S1 \\
\hline 2 & Ibu Siti Maisyaroh & S2 \\
\hline 3 & Bapak Warsono & S3
\end{tabular}

yang diberikan berdasarkan inisial dapat dilihat pada tabel 1.

Dalam penelitian ini yang dianalisis adalah etnomatematika pada Payung Geulis Tasikmalaya dalam bahasan Mata Pelajaran Matematika. Pengambilan data dilakukan dengan observasi, wawancara dan dokumentasi. Analisis dilakukan pada data tersebut sehingga akan ditemukan data valid yang berupa klarifikasi etnomatematika pada Payung Geulis.

\section{Hasil dan Pembahasan}

\section{A. Analisis data Subjek S1}

Berikut adalah cuplikan wawancara penulis dengan subjek S1.

$\mathrm{P} \quad$ : Mohon maaf Pak sebelumnya boleh ceritakan kembali mengenai sejarah Payung Geulis yang Bapak ketahui? Serta bagaimana Bapak bisa menjadi seorang pengrajin Payung Geulis?

S1 : Payung geulis itu sudah ada dari sekitar tahun 1940-an, dan di Panyingkiran ini hampir 90\% penduduknya usaha dibidang payung geulis. Setelah itu pada tahun 1980 sudah tidak ada pengrajin payung disini (di Panyingkiran). Kemudian, Uwa saya wa Syahrod memulai kembali membuka usaha payung geulis pada tahun 1984 dan alhamdulillah sampai sekarang masih berkembang sehingga dikampung saya ini ada 5 pengrajin payung, untuk kota tasik ada 7 pengrajin payung, bahkan dulu di babakan payung juga ada cuman ironisnya hanya tinggal nama dan hanya tersisa satu pengrajin saja yang masih berusaha dalam bidang payung geulis. Saya sendiri memulai usaha dari tahun 1998, awalnya belajar dari Uwa yang kebetulan seorang pengrajin Payung Geulis juga di Panyingkiran.

P : Mengenai Payung Geulis, apakah ada pertimbangan dalam menentukan ukurannya? Biasanya yang diproduksi berukuran berapa saja? 
S1 : Sebenarnya tidak ada pertimbangan karena memang dari dulu sudah seperti itu, yang membedakan hanya ukuran diameter serta jumlah rusuknya saja, dari diameter $50 \mathrm{~cm}, 70 \mathrm{~cm}, 80 \mathrm{~cm}$, $120 \mathrm{~cm}, 2 \mathrm{~m}, 2,5 \mathrm{~m}$ dan biasanya disesuaikan dengan pesanan, hanya saja yang biasa diproduksi di kisaran diameter $50 \mathrm{~cm}, 60 \mathrm{~cm}, 70 \mathrm{~cm}$ dan $80 \mathrm{~cm}$.

P : Dalam pembuatan rangka itu sendiri bahan apa saja yang diperlukan serta adakah ketentuan dalam pembuatannya?

S1 : Sebenarnya jika berbicara masalah rangka, tidak ada hal-hal yang dikhususkan saya hanya terima jadi saja dari tukang rangka.

P : Bagaimana cara menentukan kain atau kertas yang digunakan dan ukurannya?

S1 : Itu sudah ada polanya, disesuaikan saja sama ukuran diameter rangka payungnya.

P : Pada proses pemasangan benang, apa yang menjadi perhatian khusus dan benang sejenis apa yang dipakai?

S1 : Saya mempunyai pegawai khusus juga untuk tahapan ini, namun untuk jenis benang biasanya pakai benang kasur atau semacamnya yang sedikit tebal.

P : Pada tahapan melukis, bahan-bahan apa saja yang dibutuhkan serta motif seperti apa yang dijadikan pertimbangannya?

S1 : Biasanya pakai cat tembok ditambahkan dengan campuran lem. Motifnya sendiri yang tradisional saja seperti bunga, hanya saja jenis bunganya bermacam-macam.

Data hasil observasi yang dilakukan di rumah produksi Payung Geulis Mandiri, didapatkan beberapa koleksi hasil kerajinan tangan Payung Geulis yang diproduksi oleh subjek S1 (lihat gambar 1).

Gambar tersebut merupakan beberapa hasil produk dari subjek S1. Pada gambar tersebut Payung Geulis dibuat dengan bahan dasar bambu dan kertas dengan tambahan beberapa jenis motif yang berbeda. Bahan serta motif-motif di atas masih menggunakan cara yang tradisional, tetapi Payung Geulis mengalami perkembangan sehingga banyak

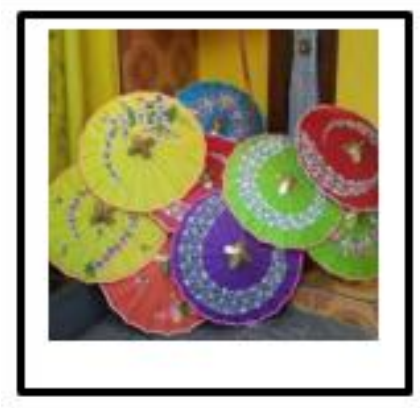

Gambar 1. Koleksi Payung Mandiri.

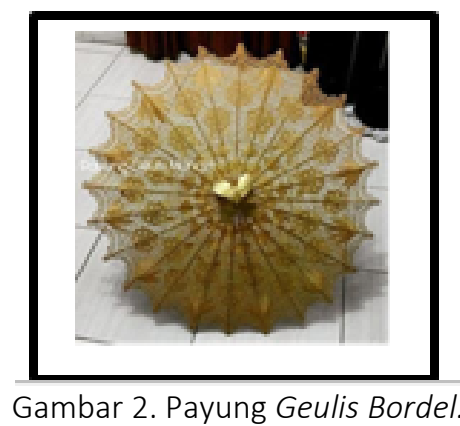

ditemukan jenis-jenis yang beragam (lihat gambar 2).

\section{B. Analisis data Subjek S2}

Berikut adalah cuplikan wawancara peneliti dengan subjek S2.

P : Maaf Bu sebelumnya boleh ceritakan kembali mengenai sejarah Payung Geulis yang Ibu ketahui? Serta bagaimana Ibu bisa menjadi seorang pengrajin Payung Geulis?

S2 : Saya kurang tahu seperti apa jelasnya untuk sejarah Payung Geulis disini karena memang sudah turun temurun dari leluhur di Panyingkiran ini. Kebetulan orang tua merupakan seorang pengrajin Payung Geulis, kemudian saya belajar sedikit demi sedikit sampai akhirnya bisa membuat sebuah Payung Geulis.

P : Mengenai Payung Geulis, apakah ada pertimbangan dalam menentukan ukurannya? Biasanya yang diproduksi berukuran berapa saja?

S2 : Tidak ada yang dijadikan pertimbangan karena ukurannya memang sudah seperti itu dari dulu, jadi hanya melanjutkan saja.

P : Dalam pembuatan rangka itu sendiri bahan apa saja yang diperlukan serta adakah ketentuan dalam pembuatannya? 
S2 : Rangka Payung Geulis ini kebetulan saya pasok dari tukang rangka, ukuran dan ketentuannya semua bagaimana tukang rangka, saya hanya menerima jadi saja terkecuali memang ada pesanan khusus dari pembeli.

P : Bagaimana cara menentukan kain atau kertas yang digunakan dan ukurannya?

S2 : Disesuaikan saja dengan ukuran diameter payungnya.

P : Pada proses pemasangan benang, apa yang menjadi perhatian khusus dan benang sejenis apa yang dipakai?

S2 : Sebenarnya kita hanya cukup mengikuti polanya saja dan untuk proses ini sudah ada ahlinya atau yang biasanya mengerjakan tahapan ini.

P : Pada tahapan melukis, bahan-bahan apa saja yang dibutuhkan serta motif seperti apa yang dijadikan pertimbangannya?

S2 : Cat lukis, alat lukis, dan motif yang akan dibuat. Biasanya yang paling diproduksi itu motif bunga.

Data hasil observasi yang dilakukan di rumah produksi Prima Art. Peneliti mendapatkan beberapa koleksi Payung Geulis dari subjek S2 (lihat gambar $3 \& 4$ ).

Gambar tersebut merupakan beberapa koleksi Payung Geulis Prima Art. Pada gambar tersebut terdapat beberapa jenis Payung Geulis yaitu Payung Geulis dari bahan kertas serta kain. Motif Payung Geulis yang dibuat

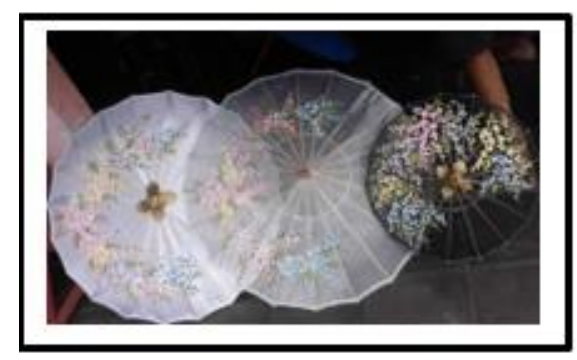

Gambar 3. Koleksi Payung Geulis Prima Art.

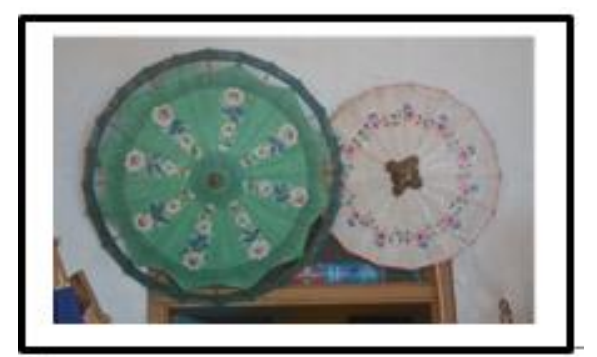

Gambar 4. Koleksi Payung Geulis Prima Art 2. pada dasarnya adalah bunga, hanya saja penempatan posisi bunganya lebih beragam.

\section{Etnomatematika pada Payung Geulis Tasikmalaya}

Hasil dari penelitian ini berupa gambaran tentang Payung Geulis yang mengandung nilai-nilai matematis khususnya dalam bahasan geometri. Setelah diamati lebih lanjut ditemukan adanya beberapa konsep matematika yang terkandung dalam bentuk dan motif payung geulis. Konsep matematika tersebut antara lain konsep geometri bangun datar, geometri bangun ruang, geometri transformasi (refleksi, translasi dan rotasi) dan kekongruenan. Tidak hanya dapat diperhatikan dari bentuk dan motifnya, namun konsep matematika ini secara tidak langsung dapat diperhatikan pada cara pembuatan motif ini, tanpa disadari bahwa budaya masyarakat pengrajin Payung Geulis telah menanamkan nilai-nilai matematis di dalamnya. Adapun kajian mengenai konsepkonsep matematika pada bentuk dan motif Payung Geulis diuraikan sebagai berikut.

\section{Konsep Geometri Bangun Datar pada}

\section{Payung Geulis}

Konsep Geometri Bangun Datar yang dimaksudkan disini adalah Bangun Datar Lingkaran. Bangun datar lingkaran yang dibuat digunakan sebagai awal pembuatan dari rangka Payung Geulis. Sebelum membuat rangka Payung Geulis, biasanya pengrajin menentukan terlebih dahulu diameter payung yang akan dibuat, kemudian menentukan jumlah jari-jarinya, barulah setelah itu pengrajin akan membuat bangun datar lingkaran dengan ukuran yang sebelumnya telah ditentukan (lihat gambar 5). 
Pada gambar tersebut terlihat bahwa titik pusat lingkaran dilambangkan dengan (O), titik pusat lingkaran berada tepat di tengah-tengah lingkaran, sedangkan jari-jari dilambangkan dengan ( $r$ ), antara jari-jari yang satu dengan yang lainnya selalu berjarak sama. Pada dasarnya jenis ataupun ukuran yang biasa diproduksi yaitu Payung Geulis dengan ukuran diameter $66 \mathrm{~cm}$ dengan jumlah jari-jari atau rusuk payung sebanyak 20 atau 22 buah. Ukuran Payung Geulis ini beragam ada yang $33 \mathrm{~cm}$ sampai dengan $1,5 \mathrm{~m}$ tergantung kebutuhan. Penentuan ukuran diameter dan jumlah jari-jari ini disesuaikan dengan keinginan konsumen, hanya saja diberikan rambu-rambu oleh pengrajin sehingga Payung Geulis tetap dapat menjaga keaslian budayanya.

\section{Konsep Geometri Bangun Ruang pada} Payung Geulis

\section{a. Bangun Ruang Kerucut}

Jika diperhatikan lebih lanjut, bagian bawah dari rangka Payung Geulis ini akan membuat sebuah bangun menyerupai kerucut yang memiliki jumlah jari-jari yang sama dengan bangun datar lingkaran yang sebelumnya telah dibuat. Bangun kerucut yang dihasilkan ini tidak memiliki selimut serta alasnya tidak tampak secara jelas (lihat gambar 6).

Kerucut merupakan gabungan dari lingkaran serta limas, dimana lingkaran merupakan alasnya. Pada Payung Geulis tersebut, jari-jari pada lingkaran ditarik ke atas yang kemudian bertumpu pada titik yang sama yaitu bagian untuk menutup atau membuka Payung Geulis. Jika diperhatikan secara detail, kita dapat melihat segitigasegitiga yang terbentuk. Jumlah segitiga tersebut setara dengan jumlah jari-jari lingkaran. Misalkan, sebuah Payung Geulis dengan diameter $66 \mathrm{~cm}$ memiliki jumlah jarijari 22 buah, sehingga bangun segitiga yang

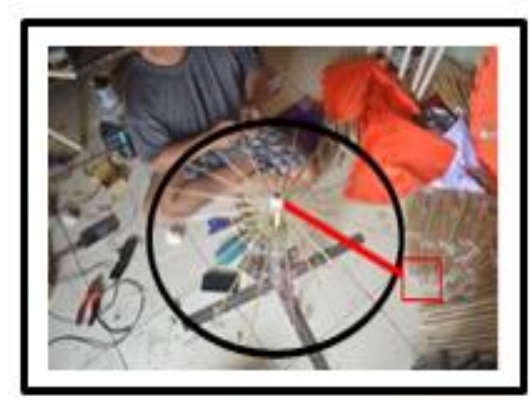

Gambar 5. Bangun Datar Lingkaran pada Rangka Payung Geulis.

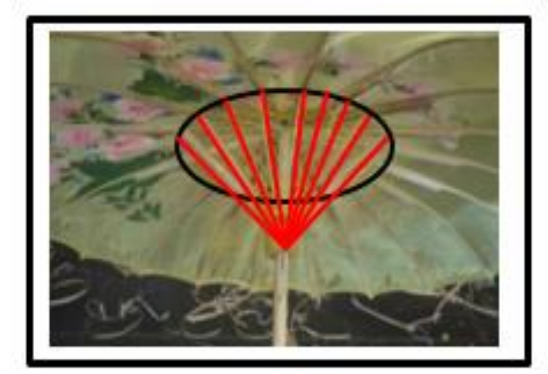

Gambar 6. Bangun Ruang Kerucut pada Payung Geulis.

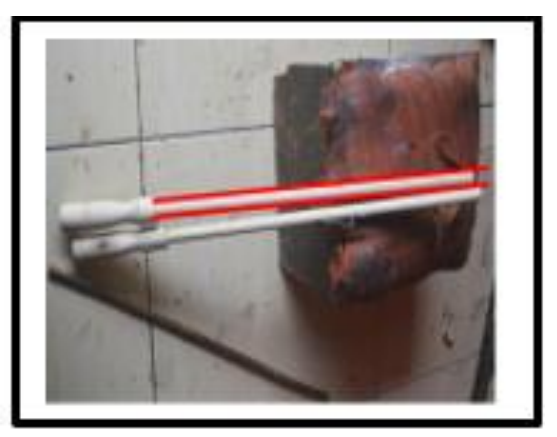

Gambar 7. Gagang Payung Geulis.

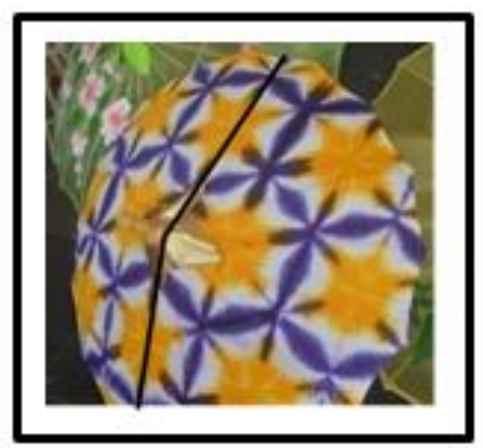

Gambar 8. Motif Simetri pada Payung Geulis 
terbentuk pada bagian penyangga Payung Geulis adalah 22 buah, nilai yang sama dengan jumlah jari-jari pada lingkaran.

\section{b. Bangun Ruang Tabung}

Bangun Ruang Tabung yang dimaksudkan disini adalah pada bagian gagang Payung Geulis. Jika diperhatikan secara seksama, gagang pada Payung Geulis ini membentuk sebuah bangun ruang tabung yang padat. Pembuatan gagang Payung Geulis ini dibuat sedemikian rupa sehingga dapat menjaga kekukuhan serta kemudahan Payung Geulis untuk dipakai (lihat gambar 7).

\section{Konsep Simetri pada Payung Geulis}

Konsep simetri yang dimaksudkan disini adalah simetri lipat. Salah satu cara pembuatan motif Payung Geulis yaitu dengan membuat sketsanya serta terlebih dahulu. Sketsa ini biasanya langsung dibuat pada kain atau kertas yang sudah terpasang pada rangka

Payung Geulis. Sebagai contoh pada pembuatan motif Payung Geulis seperti gambar 8.

\section{Konsep Geometri Transformasi Refleksi pada Payung Geulis}

Dapat juga digunakan metode sederhana lainnya dalam pembuatan motif yaitu dengan menerapkan konsep refleksi. Perhatikan gambar 10, pada gambar tersebut cukup dibuat sketsa motif a yang selanjutnya sketsa ini ditaruh di sebelah kanan, bawah atau posisi tertentu lainnya yang akhirnya akan memperoleh motif Payung Geulis yang utuh seperti gambar 9.

Gambar berikut ini menunjukkan bahwa motif pada Payung Geulis yang dipotong menggunakan sumbu X (lihat gambar 10).

Setelah dicermati secara seksama, terdapat sifat refleksi yang diterapkan pada motif
Payung Geulis yakni refleksi terhadap sumbu $X$.

Pencerminan terhadap sumbu $x$ : $P(x, y)$ sumbu $x \rightarrow P^{\prime}(x,-y), \quad$ dengan matriks pencerminan

$$
P_{x}=\left[\begin{array}{cc}
1 & 0 \\
0 & -1
\end{array}\right] \text { sehingga } P_{x}^{\prime}=\left[\begin{array}{cc}
1 & 0 \\
0 & -1
\end{array}\right]\left[\begin{array}{l}
x \\
y
\end{array}\right]
$$

\section{Konsep Geometri Transformasi Translasi pada Payung Geulis}

Konsep lain yang digunakan dalam pembuatan motif Payung Geulis adalah konsep translasi, dengan memindahkan atau menggeser sketsa motif bunga pada Payung Geulis ke posisi tertentu, tentunya cukup jelas menggambarkan bahwa konsep translasi telah diterapkan dalam pembuatan motif Payung Geulis. Contoh motif Payung Geulis pada gambar 12 , motif a digeser ke kanan sekian satuan sehingga diperoleh motif a', selanjutnya a' digeser ke kanan sekian satuan lagi sehingga diperoleh a", demikian seterusnya. Pada akhirnya diperoleh motif Payung Geulis seperti gambar 12.

\section{Konsep Geometri Rotasi pada Payung Geulis}

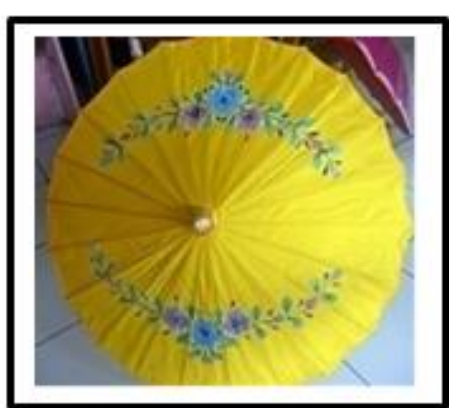

Gambar 9. Motif Refleksi pada Payung Geulis

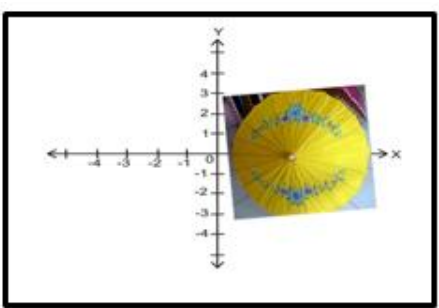

Gambar 10. Refleksi pada Motif Payung Geulis 
Pembuatan motif Payung Geulis juga dapat dikaitkan dengan konsep rotasi pada bangun datar. Dimana konsep rotasi yang dimaksud didapat dengan cara memutar motif yang dibuat sesuai dengan sumbunya. Sebagai contoh, perhatikan motif Payung Geulis pada gambar 13 . Pada gambar ini, motif a terlebih dahulu dicerminkan terhadap sumbu vertikal yaitu $y$, sehingga diperoleh $a^{\prime}$, a' ini selanjutnya dirotasi $180^{\circ}$ sehingga diperoleh a". Dari proses ini, diperoleh motif Payung Geulis pada gambar 12.

Gambar 13 adalah rotasi pada motif payung geulis di titik $O(0,0)$ dengan rotasi sejauh $180^{\circ} . \quad\left[\begin{array}{l}x^{\prime} \\ y^{\prime}\end{array}\right]=\left[\begin{array}{cc}x \cos \theta & -y \sin \theta \\ x \sin \theta & y \cos \theta\end{array}\right]\left[\begin{array}{l}x \\ y\end{array}\right]$

\section{Konsep Kekongruenan pada Payung Geulis}

Selain konsep simetri dan transformasi, pada motif Payung Geulis juga terdapat konsep lain yaitu konsep kekongruenan. Salah satu cara untuk menunjukkan bahwa dalam

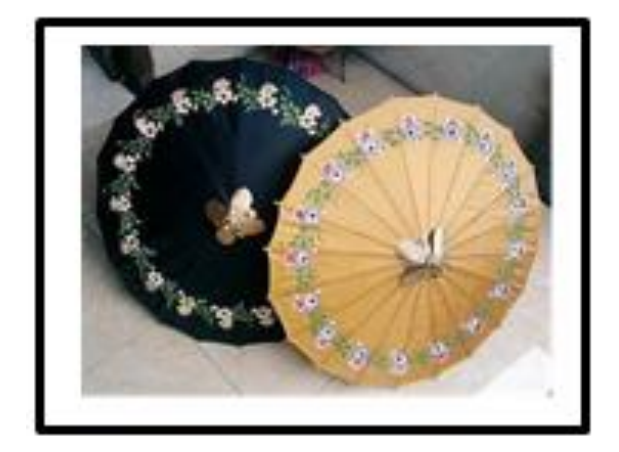

Gambar 12. Motif Translasi pada Payung Geulis

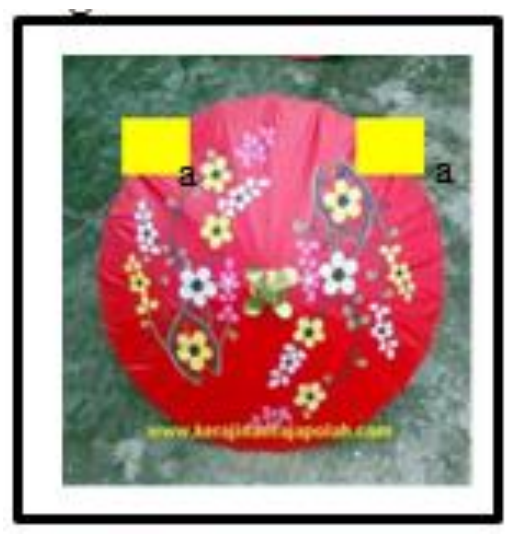

Gambar 13. Motif Rotasi pada Payung Geulis.
Payung Geulis terdapat kekongruenan pada motifnya, yaitu sketsa yang dibuat kemudian diberikan tindakan, apakah dicerminkan, digeser, atau diputar, sehingga dengan proses ini, maka diperoleh motif lainnya pada posisi lain yang memiliki ukuran dan bentuk yang sama dengan motif yang semula. Sebagai contoh yaitu gambar 14 , pada gambar ini, motif Payung Geulis terdiri dari motif bunga yang kongruen satu sama lain.

Berikut adalah ringkasan mengenai jenis dan ukuran pada pembuatan Payung Geulis (lihat tabel 2).

Berdasarkan pada hasil wawancara yang diperoleh dari subjek, proses pembuatan Payung Geulis tidaklah jauh berbeda. Para pengrajin Payung Geulis di Panyingkiran melakukan kerja sama dengan pembuat rangka payung sehingga memudahkan serta mengefisienkan waktu bagi para pengrajinnya. Kegiatan pembuatan

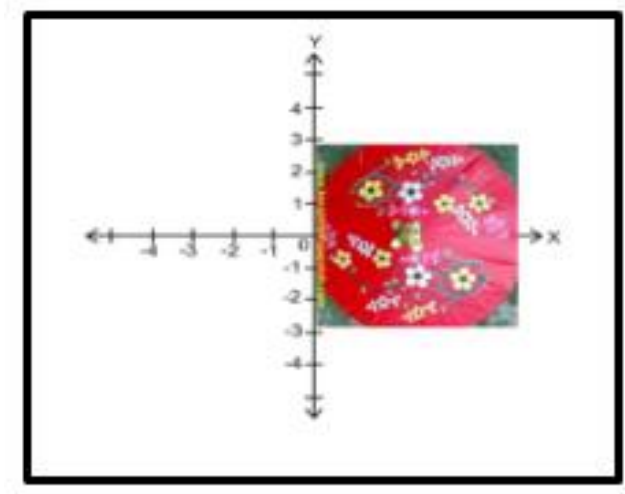

Gambar 14. Rotasi pada Motif Payung Geulis.

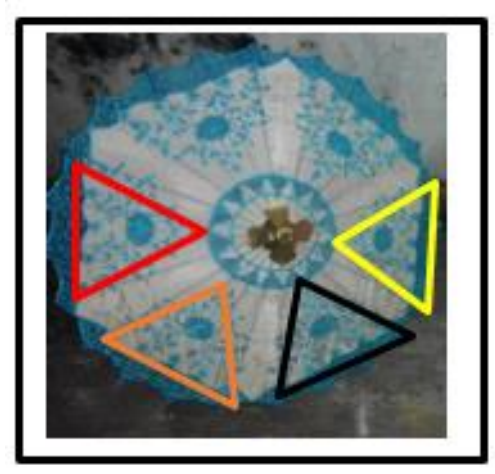

Gambar 15. Motif Kongruen pada Payung Geulis 
Payung Geulis di Panyingkiran ini berfokus pada bagian finishing saja, dimana kegiatan tersebut berupa pemasangan benang dan kertas, melukis motif pada Payung Geulis serta pemasangan gagang. Pemasaran yang dilakukan pun cukup beragam, selain dilakukan secara langsung di rumah produksi, pemasaran melalui akun media sosial seperti Facebook, Instagram, blogspot, wordpress dan lain sebagainya.

Etnomatematika dengan unsur budaya yang bersifat fisik dapat ditemukan pada Payung Geulis. Payung Geulis ternyata menggambarkan suatu lambang, konsep, prinsip serta keterampilan matematis yang diterapkan secara tidak sengaja oleh para pengrajin Payung Geulis. Konsep matematis yang diteliti pada Payung Geulis ini adalah mengenai konsep geometri.

Berdasarkan hasil penelitian, konsep geometri yang ditemukan pada Payung Geulis diantaranya simetri, geometri bangun datar lingkaran, geometri bangun ruang kerucut dan tabung, geometri transformasi (refleksi, translasi dan rotasi) dan kekongruenan. Konsep geometri simetri, geometri transformasi serta kongruen muncul pada saat tahapan pelukisan motif pada Payung Geulis, sedangkan konsep geometri bangun datar lingkaran dan bangun ruang kerucut muncul

Tabel 2.

Jenis dan Ukuran Payung Geulis

\begin{tabular}{|c|c|c|c|c|}
\hline \multirow[b]{2}{*}{$\begin{array}{c}\text { Jenis } \\
\text { Ukuran } \\
\text { Payung }\end{array}$} & \multicolumn{2}{|r|}{ Lingkaran } & \multirow{2}{*}{$\begin{array}{c}\text { Kerucut } \\
\text { Jumlah } \\
\text { Segitiga } \\
\text { yang } \\
\text { Terbentuk }\end{array}$} & \multirow[b]{2}{*}{$\begin{array}{l}\text { Tinggi } \\
\text { Tabung } \\
\text { /Gagan } \\
\text { g }\end{array}$} \\
\hline & $\begin{array}{l}\text { Dia } \\
\text { met } \\
\text { er }\end{array}$ & $\begin{array}{c}\text { Jumlah } \\
\text { Jari- } \\
\text { jari/Rusuk } \\
\text { Payung }\end{array}$ & & \\
\hline Kecil & $\begin{array}{l}55 \\
\mathrm{~cm}\end{array}$ & 18 & 18 buah & $\begin{array}{c}40-50 \\
\mathrm{~cm}\end{array}$ \\
\hline Sedang & $\begin{array}{l}66 \\
\mathrm{~cm}\end{array}$ & 20 & 20 buah & $60 \mathrm{~cm}$ \\
\hline Standar & $\begin{array}{l}84 \\
\mathrm{~cm}\end{array}$ & 20 dan 22 & $\begin{array}{c}20 \text { buah } \\
\text { dan } 22 \\
\text { buah }\end{array}$ & $75 \mathrm{~cm}$ \\
\hline
\end{tabular}

pada saat pembuatan rangka pada Payung Geulis, sedangkan bangun ruang tabung muncul pada saat pembuatan gagang Payung Geulis. Terdapat pula konsep transformasi geometri dalam motif Payung Geulis. Konsep matematika sebagai hasil aktivitas membuat pola yang dapat diungkap dari motif tersebut diantaranya translasi, refleksi dan rotasi. Kaidah ilmu matematika terkandung dalam Payung Geulis yang dibentuk dari setiap proses pelukisan yang membentuk motif berdasarkan konsep transformasi geometri.

Motif Payung Geulis ini terdiri dari beberapa macam, diantaranya motif lukis geometris (garis lurus, lengkung dan patahpatah) dan motif non-geometris (manusia, hewan dan tumbuhan). Payung Geulis memiliki motif tradisional yaitu bunga. Motif bunga tersebut dibedakan berdasarkan letak pelukisannya, seperti lingkar tengah, lingkar pinggir, berkumpul dan lainnya. Dalam konsep matematika, transformasi geometri merupakan suatu pemetaan titik pada bidang ke himpunan titik pada bidang yang sama. Jenis-jenis transformasi yang dapat dilakukan diantaranya translasi, refleksi dan rotasi. Tidak semua jenis transformasi tersebut dapat diaplikasikan pada motif Payung Geulis.

Berdasarkan hasil analisis yang telah dilakukan terdapat tiga jenis transformasi yang digunakan yaitu translasi, refleksi, dan rotasi. Melalui etnomatematika Payung Geulis ini tentu dapat memberikan inspirasi kepada pendidik untuk mengembangkan pembelajaran yang menarik dengan menerapkannya ke dalam proses pembelajaran, hal ini sejalan dengan etnomatematika yang dilakukan oleh Dewita, Mujib, \& Siregar (2019). 


\section{Penutup}

Terdapat

keterkaitan

antara

etnomatematika

Payung Geulis dalam

bahasan konsep geometri dengan materi pelajaran matematika. Keterkaitan tersebut dapat dijadikan sumber bagi mata pelajaran matematika khususnya pada jenjang sekolah dasar mengenai konsep simetri dan jenjang sekolah menengah pertama mengenai bangun datar, bangun ruang sisi lengkung, geometri transformasi dan kongruen.

Payung Geulis dapat menjadi pembelajaran yang bersifat kontekstual dan logis; dalam bahasan yang lebih luas bukan hanya dalam konsep Geometri; Dapat mencari etnomatematika yang ada pada kebudayaan masyarakat tertentu, sehingga aktivitas matematika yang tidak disadari oleh masyarakat dapat terungkap dengan luas; sebelum melakukan kegiatan penelitian, sebaiknya mempunyai dasar teori yang kuat dan runtun, sehingga aktivitas matematika dapat semuanya terungkap.

\section{UCAPAN TERIMA KASIH}

Ucapan terima kasih kepada semua pihak yang telah membantu dalam pelaksanaan penelitian ini, riset ini dibiayai oleh DRPM UNSIL dalam skema penelitian internal penelitian pengembangan kapasitas.

\section{DAfTAR PUSTAKa}

Afriansyah, E. A. (2013). Penjumlahan Bilangan Desimal Melalui Permainan Roda Desimal. Prosiding Seminar Nasional Matematika dan Pendidikan Matematika, 233-240.

Afriansyah, E. A. (2014). Addition and Substraction Numbers up to 10 through PMRI for SD/MI Level Students. International Postgraduate Colloqium of
Research in Education 3rd IPCORE 2014 Universitas Pendidikan Indonesia.

Afriansyah, E. A. (2015). Students' Misconception in Decimal Numbers. International Seminar on Teacher Education 1st ISTE UIN Suska Riau.

Afriansyah, E. A. (2016). Enhancing Mathematical Problem Posing via Realistic Approach. International Seminar on Mathematics, Science, and Computer Science Education MSCEIS.

Alangui, W. V. (2010). Stone Walls and Water Flows: Interrogating Cultural Practice and Mathematics. (Disertasi). Mathematics Education, University of Auckland, New Zealand.

Arisetyawan, A., Suryadi, D., Herman, T., \& Rahmat, C. (2014). Study of Ethnomathematics: A Lesson from Baduy Culture. International Journal of Education and Research, 2(10), 681-688.

Atmanto, E. Y. (2008). Metode Studi Kasus dalam Penelitian. Bandung: Erlangga

Barton, B. (1996). Ethnomathematics: Exploring Cultural Diversity in Mathematics. Unpublished doctoral dissertation, University of Auckland, Auckland, New Zealand.

D'Ambrosio, U., \& Ascher, M. (1994). Ethnomathematics: A Dialogue. For the Learning of Mathematics, 14 (2), 36-43.

Dewita, A., Mujib, A., \& Siregar, H. (2019). Studi Etnomatematika tentang Bagas Godang sebagai Unsur Budaya Mandailing di Sumatera Utara. Mosharafa: Jurnal Pendidikan Matematika, 8(1), 1-12. DOI: https://doi.org/10.31980/mosharafa. v8i1.202

Mulyo, M. R. G. T., Sari, A. F., \& Syarifuddin, A. (2019). Proses Berpikir Siswa Bergaya 
Kognitif Visualizer dalam Menyelesaikan Masalah TIMSS Non Geometri. Mosharafa: Jurnal Pendidikan Matematika, 8(1), 167-178. DOI: https://doi.org/10.31980/mosharafa. v8i1.435

Paraide, P. (2008). Number in the Tolai Culture. Contemporary PNG Studies DWU Research Journal, 9(2), 69-77.

Puspadewi, K. R., \& Putra, I. G. N. N. (2014). Etnomatematika di Balik Kerajinan Anyaman Bali. Jurnal Matematika, 4(2).

Sholihah, S. Z., \& Afriansyah, E. A. (2017). Analisis Kesulitan Siswa dalam Proses Pemecahan Masalah Geometri Berdasarkan Tahapan Berpikir Van Hiele. Mosharafa: Jurnal Pendidikan Matematika, 6(2), 287-298. DOI: https://doi.org/10.31980/mosharafa. v6i2.317

Siregar, N. (2016). Meninjau Kemampuan Penalaran Matematis Siswa SMP melalui Wawancara Berbasis Tugas Geometri. Mosharafa: Jurnal Pendidikan Matematika, 5(2), 128-137.

DOI: https://doi.org/10.31980/mosharafa. v5i2.268

Sugiyono. (2015). Metode Penelitian Pendidikan (Pendekatan Kuantitatif, Kualitatif, dan R\&D). Bandung: Alfabeta.

Suherman, E. (2012). Belajar dan Pembelajaran Matematika. Bandung:

Universitas Pendidikan Indonesia.

Sumardianta, J. (2013). Mempersoalkan Kurikulum 2013. [Online]. Diakses dari www.tempo.co/read/kolom/2013/03/15/ 658/Mempersoalkan-Kurikulum-2013.

Sumardyono. (2008). Karakteristik Matematika dan Implikasinya terhadap Pembelajaran Matematika. Yogyakarta: Depdiknas.
Sundawan, M. D., Irmawan, W., \& Sulaiman, H. (2019). Kemampuan Berpikir Relasional Abstrak Calon Guru Matematika dalam Menyelesaikan Soal-Soal Non-Rutin pada Topik Geometri Non-Euclid. Mosharafa: Jurnal Pendidikan Matematika, 8(2), 319330.

DOI: https://doi.org/10.31980/mosharafa. v8i2.438

Turmudi. (2009). Landasan Filsafat dan Teori Pembelajaran Matematika (Berparadigma Eksploratif dan Investigatif). Jakarta Pusat: Leuser Cita Pustaka.

\section{Riwayat Hidup PenUlis}

\section{Siska Ryane Muslim, M. Pd.}

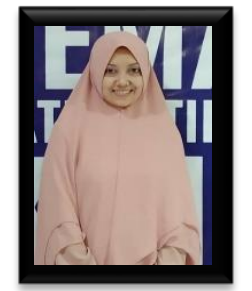

Lahir di Tasikmalaya, 28 Januari 1981. Dosen di Universitas Siliwangi. Studi S1 Pendidikan Matematika di Universitas Siliwangi, lulus tahun 2004; S2 Pendidikan Matematika di Universitas Terbuka, lulus tahun 2014.

\section{Mega Nur Prabawati, M.Pd.}

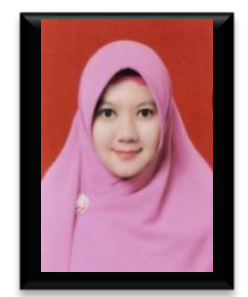

Lahir di Tasikmalaya, 24 Januari 1988. Studi S1 Pendidikan Matematika di Universitas Siliwangi, lulus tahun 2005; S2 Pendidikan Matematika di Universitas Pendidikan Indonesia, lulus tahun 2013. 